\section{INDUSTRY AND TECHNICAL EDUCATION IN GREAT BRITAIN}

$A$ CONFERENCE on "Industry and Technical Education", organized by the Regional Advisory Council for the Organization of Further Education in the East Midlands and by the North Midland Regional Council of the Federation of British Industries, was held at the College of Technology, Loughborough, on April 21, 1955, and the report of the conference has now been published*. It contains the text of the chief addresses and summaries of the discussions at the two sessions.

At the first of these sessions, which considered the relation between part-time, full-time and sandwich courses, Dr. H. L. Haslegrave, putting the point of view of the technical college, expressed the opinion that the technical college is concerned with the development of the whole man, his character and his mind, and that the best training in the application of knowledge is to use it by actually doing things. He emphasized the importance of technical colleges, as well as industry, making full use of their personnel even if it involves a policy of concentration of courses. $\mathrm{He}$ thought that the field for full-time courses of three to five years is restricted to branches of industry in which extensive practical training is unnecessary or in which facilities for such practical training do not yet exist. Courses for semi-skilled and skilled personnel, for technicians and for professional men should be regarded as of equal importance. Putting the point of view of the engineering industry, Air Commodore W. C. Cooper said that for the professional engineer or technologist a full appreciation of the economic factors is as essential as high standards of technical competence and knowledge. He thought, however, that there is a danger of overstressing the need for such men and women, because in the main the new knowledge must come from those who have received the equivalent of a full-time university education of at least three years, and he questioned the desirability of employing those so trained in technological applications. He did not think that the sandwich course is the ideal form of training for technical staffs, preferring an industrially based residual training in industrial colleges specifically created for the purpose.

Mr. R. B. Simpson, speaking for the textile industry, thought that, for persons fifteen years old leaving secondary modern schools, technical colleges provide the opportunities and encouragement to obtain the qualifications which employers can recognize as an accepted standard of achievement in their particular sections of the textile industry. The technical colleges also have to cater for grammarschool boys, particularly those who have failed to achieve the necessary subjects at the Ordinary level of the General Certificate of Education to enable them to go forward to a degree. For graduates, they provide the courses, possibly a sandwich course, leading to an associateship of the Textile Institute. The discussion also emphasized the importance of developing loyalties in young people, by showing them how their work helps both their companies and contributes to the welfare of the whole community, and the value of those who are technically qualified

* Report of the Conference on Industry and Technical Education. (Organized by the Regional Advisory Council for the Organization of Further Edueation in the East Midlands and the F. B.I. North Midland Further Education in the East Midlands and the F. B.I. North Midland
Regional Council, and held at the College of Technology, Loughborough, 21 April 1955.) Pp. ili +41 . (London: Federation of British Industries, 1955.) $4 s$. and possess the ability to get the best out of their workpeople.

The second session was concerned with the promotion of increased co-operation between industry and technical education. Mr. R. E. Wood dealt with the functions of the governing body and advisory committees of a technical college, and stressed particularly the value of part-time staff from industry. Mr. F. Stephenson, dealing with the work of local education authorities in this field, thought that the Regional Advisory Council is the most effective means for promoting increased co-operation; but he also stressed the value of adequate grants to students and of major awards for full-time students at technical colleges. Mr. J. C. McMeeking, reviewing the existing machinery for promoting co-operation, thought that, though it goes a long way towards meeting the needs, it could be improved by giving more attention to the needs of small firms and by making craft training in colleges more practical. Every effort should be made to release more teachers for periods in industry, and it is desirable to include more member's from industry on governing bodies as well as to obtain the active interest of the foremen and middle-management. Conferences of technical teachers and industrialists (including foremen) would be of mutual benefit.

\section{ENGINEERING AND PURE SCIENCE}

FOR the twenty-third Andrew Laing Lecture Fhich he delivered on December 10, 1954, to the North East Coast Institution of Engineers and Shipbuilders, Sir Edward Appleton chose as his subject "The Partnership of Science and Engineering". That there is a natural partnership between science and engineering may be illustrated by innumerable examples, current and historic, and, in developing his theme, Sir Edward selected his illustrations from widely varied fields. His aim was, however, not so much to demonstrate the existence of this partnership as to emphasize its importance under modern conditions.

Making a clear distinction between pure science and engineering based on the principle that the aim of engineering is essentially 'constructional', Sir Edward went on to consider the differences between scientific discovery and invention. A scientific discovery, he pointed out, does not necessarily involve invention, although it will, in general, increase the area of invention, and conversely an invention is not necessarily directly associated with scientific discovery. Speaking of the essential distinctive quality of invention, Sir Edward said that the inventive step must contain more than deductive reasoning. "Indeed," he remarked, "my own view is that the impact of an invention on the minds of others skilled in the art, should engender surprise."

The development of engineering as an art has from its early beginnings stimulated inventions and discoveries which can properly be classed in the field of pure science, and likewise advances in scientific knowledge have been turned to account in the practice of engineering. As a notable example of collakoration between the engineer and the pure scientist, Sir Edward referred to the development of vacuum technique during and subsequent to the First World War. Before the First World War the gas pressure 